\title{
Combined Micro- and Macro scale X-ray powder diffraction mapping of degraded Orpiment paint in a 17th century still life painting by Martinus Nellius
}

\author{
Jonas Simoen ${ }^{1}$, Steven De Meyer ${ }^{1}$, Frederik Vanmeert ${ }^{1}$, Nouchka de Keyser ${ }^{1,2,3}$, Ermanno Avranovich ${ }^{1}$, \\ Geert Van der Snickt ${ }^{1,2}$, Annelies Van Loon ${ }^{3,4}$, Katrien Keune ${ }^{3,5}$ and Koen Janssens ${ }^{1,3^{*}}$ (])
}

\begin{abstract}
The spontaneous chemical alteration of artists' pigment materials may be caused by several degradation processes. Some of these are well known while others are still in need of more detailed investigation and documentation. These changes often become apparent as color modifications, either caused by a change in the oxidation state in the original material or the formation of degradation products or salts, via simple or more complex, multistep reactions. Arsenic-based pigments such as orpiment $\left(\mathrm{As}_{2} \mathrm{~S}_{3}\right)$ or realgar $\left(\mathrm{a}-\mathrm{As}_{4} \mathrm{~S}_{4}\right)$ are prone to such alterations and are often described as easily oxidizing upon exposure to light. Macroscopic X-ray powder diffraction (MA-XRPD) imaging on a sub area of a still life painting by the 17th century Dutch painter Martinus Nellius was employed in combination with microscopic $(\mu-)$ XRPD imaging of a paint cross section taken in the area imaged by MA-XRPD. In this way, the in situ formation of secondary metal arsenate and sulfate species and their migration through the paint layer stack they originate from could be visualized. In the areas originally painted with orpiment, it could be shown that several secondary minerals such as schultenite $\left(\mathrm{PbHAsO}_{4}\right)$, mimetite $\left(\mathrm{Pb}_{5}\left(\mathrm{AsO}_{4}\right)_{3} \mathrm{Cl}\right)$, palmierite $\left(\mathrm{K}_{2} \mathrm{~Pb}\left(\mathrm{SO}_{4}\right)_{2}\right)$ and syngenite $\left(\mathrm{K}_{2} \mathrm{Ca}\left(\mathrm{SO}_{4}\right)_{2} \cdot \mathrm{H}_{2} \mathrm{O}\right)$ have formed. Closer inspection of the cross-sectioned paint layer stack with $\mu$-XRPD illustrates that the arsenate minerals schultenite and mimetite have precipitated at the interface between the orpiment layer and the layer below that is rich in lead white, i.e. close to the depth of formation of the arsenate ions. The sulfate palmierite has mostly precipitated at the surface and upper layers of the painting.
\end{abstract}

Keywords: X-ray powder diffraction, Non-invasive imaging, Paintings, Arsenic-based pigments, Degradation

\section{Introduction}

Photochemically and atmospherically induced alterations in artists' pigments are the result of several degradation processes, some of which are already well known while others are still in need of more detailed investigation and documentation. These alterations can often be visually perceived as color changes, either caused by a change in the oxidation state in the original material or

\footnotetext{
*Correspondence: koen.janssens@uantwerpen.be

${ }^{1}$ AXES Research Group, Department of Chemistry, Faculty of Science, University of Antwerp, Groenenborgerlaan 171, 2020 Antwerp, Belgium Full list of author information is available at the end of the article
}

the formation of degradation products or salts, via simple or more complex, multistep reactions [1-4].

Degradation phenomena, and the subsequent discoloration or loss of structural integrity of paint layers they entail, are often the result of intricate physicochemical processes that are taking place within or at the surface of paint layers. They are triggered by either internal factors, such as the co-presence of mutually incompatible pigment or pigment/binder mixtures, or external factors, such as environmental conditions (relative humidity, light, and temperature), biological activity, volatile organic compounds, pollution or human interventions, or several of these together [5]. 
Arsenic-based pigments such as natural orpiment $\left(\mathrm{As}_{2} \mathrm{~S}_{3}\right)$ or natural realgar $\left(\alpha-\mathrm{As}_{4} \mathrm{~S}_{4}\right)$ are subject to such modifications and are often described as easily oxidizing upon exposure to light [6-8].

In a number of recent studies, the oxidation of the arsenic sulfides to $A s(V)$-species has been described $[9,10]$. In several multicolored flower piece paintings by the 17th century painter Jan Davidz. de Heem, the formation of rare arsenate minerals such as mimetite $\left(\mathrm{Pb}_{5}\left(\mathrm{AsO}_{4}\right)_{3} \mathrm{Cl}\right)$ and schultenite $\left(\mathrm{PbHAsO}_{4}\right)$ was observed, co-localized with sulfate salts such as palmierite $\left(\mathrm{K}_{2} \mathrm{~Pb}\left(\mathrm{SO}_{4}\right)_{2}\right)$, syngenite $\left(\mathrm{K}_{2} \mathrm{Ca}\left(\mathrm{SO}_{4}\right)_{2} \cdot \mathrm{H}_{2} \mathrm{O}\right)$ and gypsum $\left(\mathrm{CaSO}_{4} \cdot 2 \mathrm{H}_{2} \mathrm{O}\right)$ [11].

In one of these studies, the hypothesis is formulated that the resulting arsenate ions can migrate through the paint layer stack before precipitating in the form of rare arsenate minerals [9].

By employing Macroscopic X-ray powder diffraction imaging (MA-XRPD) on a sub area of a still life painting by the 17th century Dutch painter Nellius in combination with Microscopic $(\mu-)$ XRPD imaging of a paint cross section taken in the area imaged by MA-XRPD, the in situ formation of secondary metal arsenate and sulfate species and their migration through the paint layer stack they originate in, is studied. The main motivation for performing this study is to gain a better understanding of the spontaneous transformation processes that can affect historical paint(ing)s containing arsenic-sulphide based pigments and how such alterations can change the visual outlook and mechanical stability of the affected paint.

\section{The painting and its painter}

Since 1898, the painting Still life with Quinces, Medlars and a Glass (Fig. 1), is part of the collection of the Rijksmuseum acquired by bequest of Dr Daniel Franken Dzn (Amsterdam, 1838-1898) [12].

Martinus Nellius is a Dutch still life painter from the Golden age. Little is known about his life. A first mention of the painter was in 1669 where a fruit piece by 'Niellius' was listed in an inventory in Amsterdam. The birthplace of Nellius is unknown, but one record places the painter in Leiden in 1674. According to Buijsen et al. [13], he moved to The Hague where his presence was recorded for the first time in 1676 and later in October 1719, the date of his death [14].

The oeuvre of Martinus Nellius is rather modest and his works are little studied, consisting of more or less seventeen paintings, mostly signed and a few dated between 1673 and 1694 [15]. The format of the paintings is quite consistent: a small rectangle (portrait format) still life painted with a preference for oil on panel with sizes

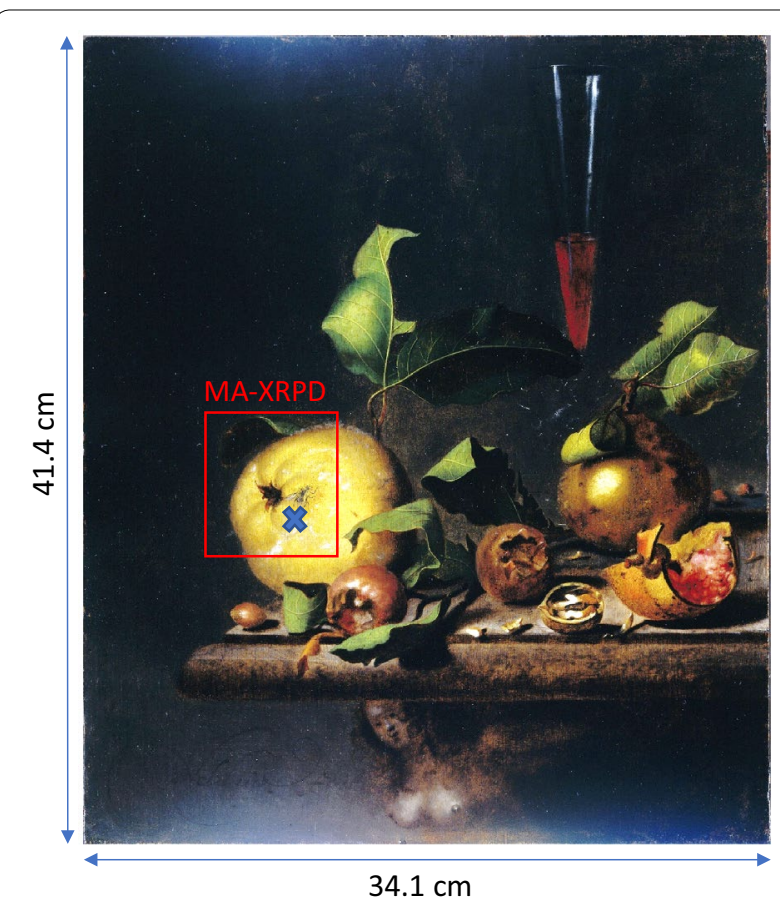

Fig. 1 Still life with Quinces, Medlars and a Glass by Martinus Nellius (SK-A-1751, Rijksmuseum Amsterdam, The Netherlands) on an oak wood panel measuring $41.4 \times 34.1 \mathrm{~cm}(\mathrm{~V} \times \mathrm{H})$. Cross indicates sampling location of paint cross-section R36-3. Rectangle indicates area of MA-XRF/XRPD scanning

ranging between $20 \times 15 \mathrm{~cm}$ and $44 \times 38 \mathrm{~cm}$. Only four signed paintings are larger in size and were painted on canvas.

Objects that typically reoccur in Nellius' oeuvre, are e.g. half peeled lemons displayed in a Roemer glass or oranges, medlars, quinces, oysters usually visited by flies and butterflies. In the painting discussed in this article, Nellius painted a pair of quinces, remnants of a recently crushed walnut, hazelnuts, medlars and an open quarter of a pomegranate with a Venetian flute glass situated on the left corner of a tabletop. Nellius painted Still life with Quinces, Medlars and a Glass on an oak wood panel measuring $41.4 \times 34.1 \mathrm{~cm}$. The painting is signed in the lower left corner as 'Nellius Fecit' but is not dated. A dendrochronology study from 1998 by Dr. Peter Klein from the University of Hamburg places the cut-date not earlier then 1667 and the possible creation of the painting as of 1669 [16]. Presumably the painting was created between 1669 and 1719.

In conjunction with the exhibition "Still life paintings from the Netherlands 1550-1720" in the Rijksmuseum in 1999, various key still life paintings from the collection, among which the little panel of Nellius, were examined and sampled. In regard to his contemporary painters, such as Jan Davidsz. de Heem and Abraham Mignon, 
Nellius did not employ a complex elaborate multi-layered painting technique. The subjects were painted with one or two precise paint layers, often beneficially leaving the grey imprimatura base tone visible. A cross-section was taken from the left quince before restoration. It revealed the presence of the arsenic-based yellow pigment orpiment to paint the quinces. Originally, the orpiment must have given the quince a brighter yellow appearance then the now crumbly, dull, greyish and powdery outlook the fruit surface now features. This altered appearance became clear during restoration after varnish removal and was the motivation for the investigations described below [15].

In art history, the iconological meaning of quinces is associated with immortality ${ }^{1}$ while the visiting fly may symbolically refer to the contradiction of immortality, i.e. the transient nature of the fruit itself.

\section{Experimental}

The first part of the study involved the examination of the entire painting by means of a commercial MA-XRF instrument [18]. This allowed to pinpoint the areas in which As-containing pigments were present. In a second phase, MA-XRPD imaging experiments were carried out on a small area-see rectangle in Fig. 1-using a mobile MA-XRF/XRPD scanning instrument that was operated in reflection mode $[11,19,20]$. Within this area, in order to study the in-depth distribution of primary and secondary compounds, a paint sample was taken. The resulting material was prepared as a cross section and analyzed by means of $\mu$-XRPD mapping at the Hard X-ray microprobe end station of beamline P06 (PETRA-III facility, Hamburg, Germany).

\section{Large-scale MA-XRF mapping}

A commercially available MA-XRF scanner 'M6 Jetstream' from Bruker Nano GmbH (Berlin, Germany) was employed for recording elemental maps of the entire painting. The M6 Jetstream consists of a $30 \mathrm{~W}$ Rh-target microfocus $\mathrm{X}$-ray tube with a maximum voltage of $50 \mathrm{kV}$, a maximum current of $0.6 \mathrm{~mA}$, a polycapillary lens, and a $30 \mathrm{~mm}^{2} \mathrm{X}$-Flash silicon drift detector that is moved over the surface of the painting by means of an $X$, Y-motorized stage, enabling a scan area of $80 \times 60 \mathrm{~cm}^{2}$ [18]. A spot size of $150 \mu \mathrm{m}$ was set for the measurements. The large-scale elemental distribution maps were collected with a step size of $300 \mu \mathrm{m}$ and dwell time of $50 \mathrm{~ms} / \mathrm{step}$, covering the complete surface of the painting $\left(34.1 \times 41.4 \mathrm{~cm}^{2}\right.$ corresponding to $963 \times 1232$ pixels). In the experimental conditions employed for many

${ }^{1}$ See Ref [17]. elements, the detection limits for MA-XRF situate themselves in the range $0.1-1 \%$.

\section{Combined MA-XRF/XRPD mapping}

For the reflection mode MA-XRF/XRPD measurements, a self-built system $[11,19,20]$ consisting of a low power $\mathrm{X}$-ray micro source $(50 \mathrm{~W}, \mathrm{I} \mu \mathrm{S}-\mathrm{Cu}$, Incoatec $\mathrm{GmbH}$, Germany) was employed, delivering a monochromatic $\left(\mathrm{Cu}-\mathrm{K}_{\alpha} ; 8.04 \mathrm{keV}\right)$ and focused X-ray beam with a photon flux of $2.9 \times 10^{8}$ photon $\mathrm{s}^{-1}$ (focal spot diameter: ca. $140 \mu \mathrm{m}$; output focal distance: ca. $20 \mathrm{~cm}$; divergence: 2.4 mrad). An incident angle of $12^{\circ}$ was chosen between the primary X-ray beam and the painting's surface, resulting in an enlarged beam footprint of around $1.5 \mathrm{~mm}$ in the horizontal direction; in the vertical direction the beam dimension is around $0.14 \mathrm{~mm}$. Diffraction patterns were recorded with a PILATUS $200 \mathrm{~K}$ area detector (Dectris Ltd., Switzerland) that was positioned on the front side of the artwork with an angle below $30^{\circ}$ between the area detector and the painting. To reduce the effects of local topography and curvature of the painting's surface on the collected diffraction data, the distance between the artwork and the instrument was automatically adjusted with a laser distance sensor (Baumer $\mathrm{GmbH}$, Germany) at each measurement point in the scanning process. This instrument was also equipped with a Vortex-Ex SDD detector (SII, USA), collecting X-ray fluorescence radiation from the front side of the painting. The previously described components were placed on a motorized platform, capable of moving the scanner in the XY (range: $25 \mathrm{~cm} \times 10 \mathrm{~cm}$ ) plane. The artwork was placed on a motorized easel, capable of moving the painting in the vertical $(\mathrm{Z}$, range: $10 \mathrm{~cm})$ direction. Calibration of several instrumental parameters was performed with a thin calcite paint layer applied on a mockup canvas. During the MA-XRF/XRPD imaging experiment an area of $6.5 \times 7 \mathrm{~cm}^{2}$ was scanned (see Fig. 1) using a step size of $1 \times 1.4 \mathrm{~mm}$ in the horizontal and vertical directions. This represents only a small fraction of the total area of the painting. An XRPD acquisition time of 10 s/pixel was employed. The detection limit of MA-XRPD for specific crystalline compounds is rather variable; compounds containing $\mathrm{Pb}$ - (or similar heavy elements) are most easily detected while organic crystalline compounds are the most difficult. Mutual overlap of diffraction lines can also strongly influence these values in the negative sense. In the measurement conditions employed, interferencefree detection limits are estimated to be of the order of $5-10 \%$.

\section{Micro-XRPD mapping}

$\mu$-XRPD data collection was done at the microprobe hutch of the Hard X-ray micro/nanoprobe beamline 
(P06) of the PETRA III storage ring (DESY, Hamburg, Germany) [21], using a primary photon energy of $21 \mathrm{keV}$, which is selected by means of a $\mathrm{Si}(111)$ double crystal monochromator. A Kirkpatrick-Baez mirror optic was employed to focus the beam, achieving a size of $0.5 \times 0.5 \mu \mathrm{m}^{2}(\mathrm{~h} \times \mathrm{v})$. A Keyence optical microscope equipped with a perforated mirror allowed for positioning of the sample. Diffraction signals were recorded in transmission geometry using an EIGER X 4M area detector (Dectris Ltd., Switzerland). Calibration of the diffraction setup was performed by means of ${\mathrm{a} \mathrm{LaB}_{6}}_{6}$ reference sample. The total size of the sample was of the order of $500 \times 600 \mu \mathrm{m}^{2}$ and was embedded in resin and polished prior to analysis. In total an area of $200 \times 110 \mu \mathrm{m}^{2}$ was scanned using a step size of $1 \times 0.5 \mu \mathrm{m}^{2}$ in respectively the horizontal and vertical direction. Diffraction patterns were acquired with $0.25 \mathrm{~s} /$ pixel exposure time. This exposure time per pixel is so short that beam damage (e.g. beam induced oxidation of reduced As species) can be excluded.

\section{Data processing}

Crystalline phase distribution maps (both macroscopic and microscopic) were obtained by full pattern refinement using the XRDUA software package [22]. The individual diffractograms were fitted to a background term and a linear combination of peak groups [23]. Each peak group contained the Bragg peaks of one crystalline phase and has three parameters that were refined during the fit process: the sample-detector distance, a scaling factor and a width factor. The scaling factor is proportional to the total volume of scattering material for a given phase and is shown in the distribution maps presented in this work. The software packages PyMCA and DataMuncher were used to create the elemental distribution maps (see [24] for details). To avoid overlap between $\mathrm{Pb}-\mathrm{L}$ and As-K XRF signals, the $K_{\beta}$-line of As was employed for mapping this element.

\section{Results and discussion}

\section{High-resolution MA-XRF images of the entire painting}

In Fig. 2, a series of MA-XRF images of the entire painting are shown, as well as two false color composites of the area around the left quince. While the $\mathrm{Ca}-\mathrm{K}, \mathrm{Pb}-\mathrm{L}$ and $\mathrm{Pb}-\mathrm{M}$ images mostly clearly show the painted composition as a whole, they are less informative in a chemical sense. The light green of the foliage can be associated with high levels of $\mathrm{Sn}$ and $\mathrm{Cu}$, suggesting that a mixture of lead tin yellow and either a $\mathrm{Cu}$-green (e.g. malachite and/ or verdigris) or a $\mathrm{Cu}$-blue (e.g. azurite) was used to obtain this tint of green. The darker greens are also associated with these two elements but show a lower $\mathrm{Sn}-\mathrm{L}$ intensity, possibly because of the presence of a lake layer (rich in $\mathrm{K}$ and $\mathrm{Ca}$ ) that covers the lighter green paint below, resulting in a darker appearance. The association of the darker parts of the foliage with higher $\mathrm{K}$ signals can clearly be seen in the As, K, Pb composite MA-XRF image of Fig. 2. The yellow parts of the painting (the yellow quince and the pomegranate fragment) have been painted with an As-containing pigment, possibly orpiment $\left(\mathrm{As}_{2} \mathrm{~S}_{3}\right)$ or realgar $\left(\mathrm{As}_{4} \mathrm{~S}_{4}\right)$ or a mixture of both. Next to a high $\mathrm{K}-\mathrm{K}$ signal, the left brown medlar is associated with a high $\mathrm{Ca}-\mathrm{K}$ intensity, but this signal may originate in part from the ground layer beneath (see further). In the bottom composite image of Fig. 2, it can clearly be seen that slightly shaded edges and ridges of the quince and the crown leaves correspond to higher Ca signals, possibly due to the local presence of bone black. Another source of Ca may be the substrate of the red lakes. None of the depicted fruits, with the exception of the details of the walnut, show elevated $\mathrm{Fe}-\mathrm{K}$ signals, generally excluding the use of earth pigments. An unclear structure is present in the left upper part of the background for which an Fecontaining paint was used; since this causes the $\mathrm{Pb}-\mathrm{M}$ signals to be absorbed, this material may be present in a superficial retouching layer. In the area of the quince (and of the walnut), extensive retouching with a Ti-containing pigment (probably $\mathrm{TiO}_{2}$, see further) has been done. In the $\mathrm{K}-\mathrm{K}, \mathrm{Ca}-\mathrm{K}, \mathrm{Pb}-\mathrm{M}, \mathrm{Sn}-\mathrm{L}$ and $\mathrm{Cu}-\mathrm{K}$ images, parts of a two-toned leaf (now hardly visible with the naked eye), positioned just above the quince, can be discerned.

\section{Macroscopic X-ray powder diffraction mapping of a degraded yellow paint area}

In Fig. 3, macroscopic distributions of specific chemical elemental and crystalline phases of a small subarea of the painting are shown. This subarea is indicated in Fig. 1 and corresponds to the upper left corner of the left quince that exhibits a greyish-pale yellow appearance. This quince is suspected to have had a much more saturated light-yellow color, typical of quinces. Since the X-ray beam impinges the painting under a shallow angle (of around $12^{\circ}$ ), only the most superficial paint layers (approximately the top 5-10 micrometers) are sampled $[11,25]$. By combining information of the large scale (Fig. 2) and small scale MA-XRF maps (Fig. 3, upper panel) with the visual color of the investigated area and with background knowledge on common painters' pigments available in 17th C Amsterdam, already an approximate identification of the pigments employed for painting the quince can be made.

It is clear from the diffraction maps that the resolution of reflection mode MA-XRPD is insufficient to map out fine details such as the insect visiting the quince. The grey/black pigment in this feature is also not detected by XRPD. Some of the lower resolution/small scale 

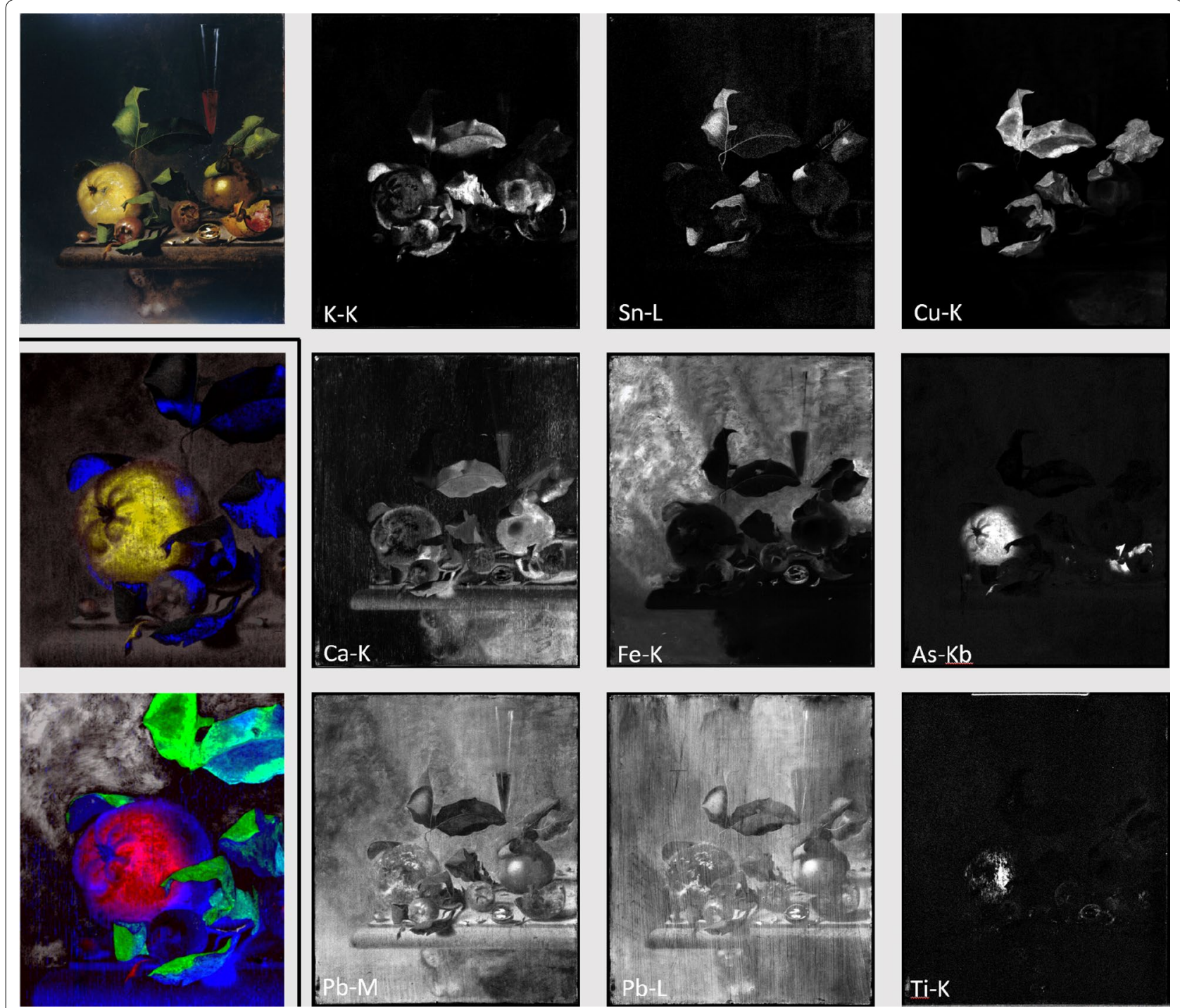

Fig. 2 MA-XRF images of the painting shown in Fig. 1. Top left: optical image; grey scale images show single element distributions, with lighter gray values indicating higher XRF signals. Middle and bottom images of left row show zoomed area of left quince: (middle) composite false color image

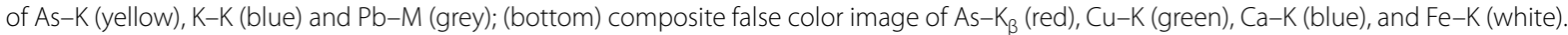
Darker parts of the foliage correspond to higher K signals; slightly shaded areas of the quince correspond to higher Ca signals

MA-XRF maps of Fig. 3 were recorded with an $8.04 \mathrm{keV}$ primary beam during the combined MA-XRF/MAXRPD scans; these include elemental distributions such as $\mathrm{S}, \mathrm{P}$ and $\mathrm{Cl}$ that could not be detected by the commercial MA-XRF instrument in the conditions used here (polychromatic primary beam of higher energy, 5-22 keV range; and a much shorter dwell time). Several XRF maps (such as those of $\mathrm{Ca}, \mathrm{K}, \mathrm{P}, \mathrm{Mn}$ and $\mathrm{Fe}$ ) allow to visualize the aforementioned two-toned leaf, situated in the upper left corner of the imaged area. The green shade of this leaf has been realized with a pigment that contains $\mathrm{Sn}$, likely lead tin yellow. Some of the darker parts of the scanned area (such as the crown leaves of the quince) are associated with higher $\mathrm{P}-\mathrm{K}$ levels, suggestive of the use of (phosphate-rich) bone black in these areas. Other dark areas (background, crown leaves) are associated with Mn and Fe (not included in Fig. 3), suggestive of the use of earth pigments (and more in particular umber or Siena earths) to obtain the dark color. The $\mathrm{S}-\mathrm{K}$ and As-K distributions clearly correspond to the yellow areas and thus very likely with an As-sulfide pigment such as orpiment (the presence of realgar is also consistent with the $S$ and As distributions but the yellow colour makes this less likely). Clearly no lead tin yellow was employed to paint 


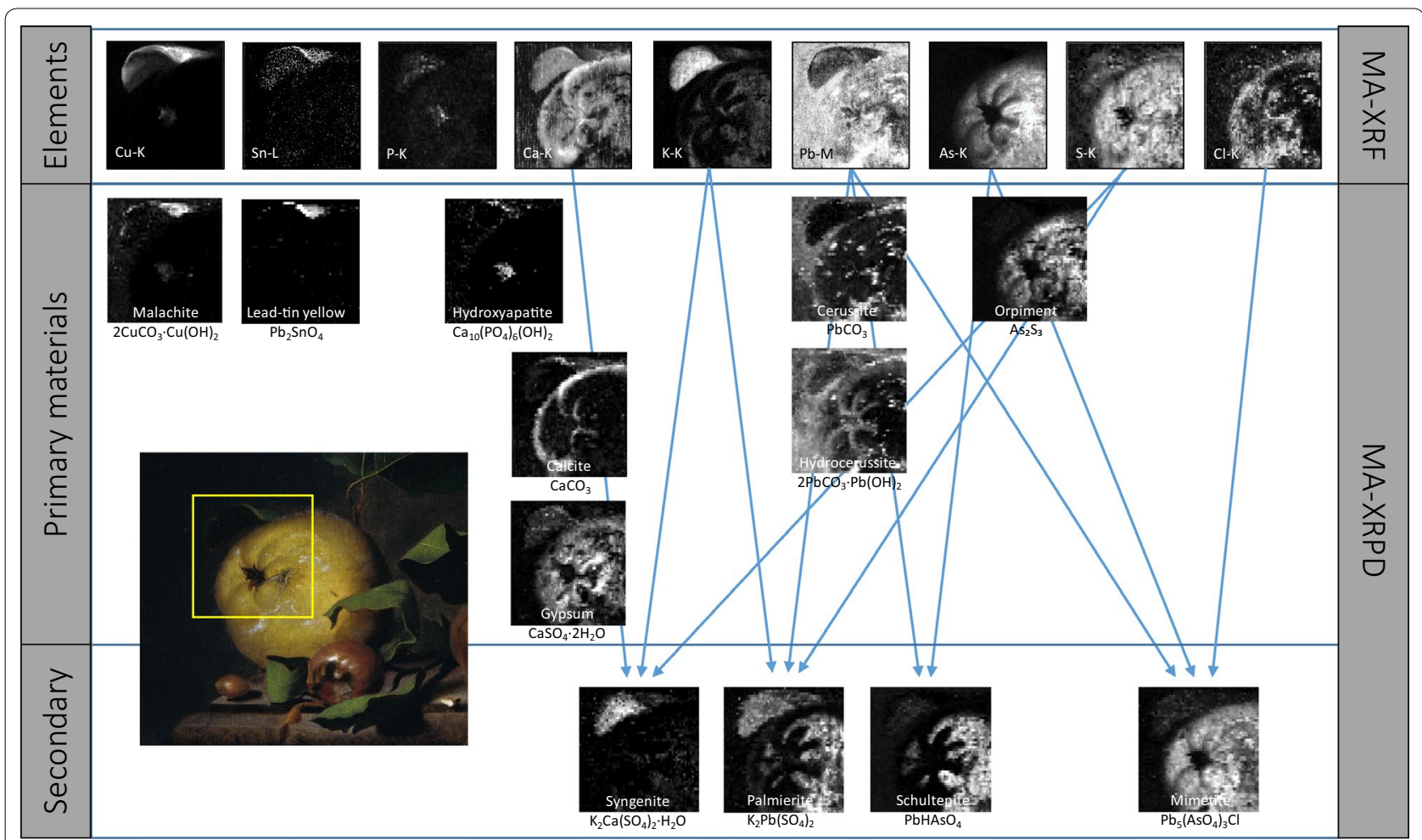

Fig. 3 Elemental and phase specific maps of a sub area $\left(6.5 \times 7 \mathrm{~cm}^{2}\right)$ of the painting showing part of the left quince and an adjacent leaf. Top panel: MA-XRF maps of various elements; middle panel: MA-XRPD distributions of several crystalline compounds, assumed to have been originally present in the paint; lower panel: MA-XRPD distributions of secondary minerals, formed in situ. Arrows link elemental and secondary mineral distributions

the yellow fruit. The bright areas of the $\mathrm{Pb}-\mathrm{M}$ map seem to resemble the map of $\mathrm{Cl}-\mathrm{K}$, suggesting that a $(\mathrm{Pb}, \mathrm{Cl})$ containing compound may be present. In some areas, the $\mathrm{Pb}-\mathrm{M}$ distribution is complementary to that of $\mathrm{Ca}-\mathrm{K}$, suggesting that a $\mathrm{Pb}$-containing material is present on top of a Ca-containing paint layer. The presence of $\mathrm{Ca}$ in the yellow area is not illogical since gypsum is known to have been added to orpiment-based paints [26]. There are, however, significant differences among the $\mathrm{S}-\mathrm{K}$ and $\mathrm{Ca}-\mathrm{K}$ distributions. The $\mathrm{K}-\mathrm{K}$ and $\mathrm{Cl}-\mathrm{K}$ distributions appear complementary to each other and are not so easily associated with a specific pigment. Together with $\mathrm{Ca}-\mathrm{K}$, the $\mathrm{K}-\mathrm{K}$ map does reflect to some extent the areas on the surface of the fruit where shadows were painted and thus the $\mathrm{K}-\mathrm{K}$ distribution may reflect (in part) the presence of (red) lakes applied on top of the yellow paint. The same could be true for $\mathrm{Ca}-\mathrm{K}$ in case a lake was employed precipitated onto a Ca-containing inorganic substrate. Generally speaking, however, the $\mathrm{Pb}-\mathrm{M}, \mathrm{Cl}-\mathrm{K}, \mathrm{K}-\mathrm{K}, \mathrm{Ca}-\mathrm{K}$ are not easily interpretable in terms of either pigments or other materials present based on their XRF data alone.

A more specific pigment identification is possible when the corresponding MA-XRPD maps are considered (Fig. 3, middle and lower panel) in comparison to the corresponding elemental maps (also shown in Fig. 3, upper panel). The $\mathrm{As}_{2} \mathrm{~S}_{3}$ map clearly confirms the use of only orpiment (i.e. no realgar encountered above the detection limit of MA-XRPD) for painting the yellow fruit. Lead tin yellow (another yellow pigment) is only used in the green of the leaf. Both in the leaf and in the crown leaves of the quince some hydroxyapatite (bone black) is present. The gypsum distribution resembles that of orpiment while that of calcite is largely confined to the (slightly shaded) edges of the quince and ridges around the crown leaves. In this particular area, the hydrocerussite distribution is somewhat similar to that of calcite. Cerussite and hydrocerussite appear to be co-localized in the white highlights that were applied on the yellow surface of the quince.

Next to orpiment, of which the presence in a 17th century painting can be expected/is plausible, also the rare As-containing minerals schultenite $\left(\mathrm{PbHAsO}_{4}\right)$ and mimetite $\left(\mathrm{Pb}_{5}\left(\mathrm{AsO}_{4}\right)_{3} \mathrm{Cl}\right)$ are found to be present in the general yellow area, but with distributions that are quite different from each other. Consistent with the recent literature on this topic $[9,11]$, the rare nature of these minerals strongly suggests that they are secondary products. These were not part of the paint employed by Nellius 
during the creation of the painting and were formed in the course of the past 350 years on or near the surface of the paint as a result of spontaneous chemical transformation processes. Indeed, both orpiment and realgar are known to be light-sensitive, causing their color to fade [6]. For orpiment, a direct photo-oxidation to arsenolite $\left(\mathrm{As}_{2} \mathrm{O}_{3}\right)$ takes place, while in the case of realgar an intermediate, pararealgar $\left(\mathrm{As}_{4} \mathrm{~S}_{4}\right)$, is initially formed [27-29]. Recently it was found that in a subsequent oxidation step arsenolite can be further transformed into soluble arsenates [9].

Other secondary products that are found on this flower still life are palmierite $\left(\mathrm{K}_{2} \mathrm{~Pb}\left(\mathrm{SO}_{4}\right)_{2}\right)$ and syngenite $\left(\mathrm{K}_{2} \mathrm{Ca}\left(\mathrm{SO}_{4}\right)_{2} \cdot \mathrm{H}_{2} \mathrm{O}\right)$, two mixed $\mathrm{K}$-based sulfates with either $\mathrm{Ca}^{2+}$ or $\mathrm{Pb}^{2+}$ as divalent ions. Both these secondary products are abundantly present in the leaf above the quince where they have the same distribution. In the yellow areas, they are also present but only with a partially similar distribution. In the MA-XRPD data, no indication of the presence of the alum substrate of the lakes (assumed to be a primary material) is visible in this case, suggestion that most or all of it became converted into other sulphates. Both secondary sulfates are less abundantly present in the radial areas around the crown leaves of the quince where there is also less schultenite and less $\mathrm{K}$ (see XRF image) present. In turn, somewhat more $\mathrm{Ca}$, corresponding to calcite and gypsum, as well as more hydrocerussite are found in this region. While the cerussite image largely resembles the hydrocerussite distribution, it does not show a higher abundance in the aforementioned radial areas. The comparison of the $\mathrm{Ca}$ MA-XRF map with the MA-XRPD map of calcite, bone black (hydroxyapatite), gypsum and syngenite clearly shows the different spatial distribution of these four calcium compounds. The MA-XRPD map of lead tin yellow is quasi identical to the Sn-L MA-XRF map, identifying this traditional yellow pigment as the single Sn-containing compound present. In the brighter green of the leaf, and to a lesser extent in the crown leaves and in the background area, malachite is shown to be present.

Syngenite is a frequently encountered secondary salt, either as a weathering product in black crusts or as efflorescence layers on stone monuments, mural paintings and medieval (K-rich) glass [30-36]. In some cases it has been found below the surface of artworks, such as in a red-orange Baroque bole ground or as a raw material in the plaster of a Chinese wall painting $[37,38]$. On the other hand, palmierite is less commonly reported as a sulfate salt on stone sculptures, medieval glass windows and wall paintings [39-41]. Palmierite has been encountered in multiple paintings from 17th century Old Masters such as Vermeer, Jordaens and Rembrandt [42]. After migration of $\mathrm{Pb}^{2+}$ from lead white to upper paint layers, it can react with $\mathrm{K}^{+}$(present in e.g. smalt, lake substrates and earth pigments) and $\mathrm{SO}_{4}{ }^{2-}$ (present in lake substrates, such as potassium alum $\left(\mathrm{KAl}\left(\mathrm{SO}_{4}\right)_{2} \cdot 12 \mathrm{H}_{2} \mathrm{O}\right)$, or from environmental $\mathrm{SO}_{2}$ ) to precipitate as palmierite [42-44].

It is noteworthy that the schultenite distribution is quite different from that of the parent pigment orpiment, and similar to that of $\mathrm{K}$ and palmierite, suggesting that the formation of schultenite is facilitated when more $\mathrm{K}$ is locally present at or just below the surface, e.g. in lake brush strokes. In the very K-rich parts of the scanned areas (especially the leaf above the quince), $\mathrm{K}$ also appears to have become the preferred cationic partner for capturing sulfate ions; it would appear that in the presence of both $\mathrm{Ca}^{2+}$ and $\mathrm{Pb}^{2+}$ ions (next to $\mathrm{K}^{+}$), the sulfates syngenite and palmierite coprecipitated.

Although, based on these maps, certain hypotheses on the formation of these various salts can be made, it remains very difficult/impossible to infer information on the depth ordering of the various primary and secondary products that can be identified. Do the secondary arsenate compounds form (i) on top of orpiment, (ii) in the same stratum as their parent compound or (iii) below it? Have the secondary sulfates coprecipitated with schultenite on the surface of the painting or are they located at different depths below the surface. To obtain more information about the sequence of these layers, a paint cross section taken from the central part of the quince was examined.

\section{Microscopic X-ray powder diffraction mapping of a minute paint cross section}

In Fig. 4, two composite false color maps of relevant primary and secondary crystalline compounds obtained by $\mu$-XRPD from a minute paint cross section sampled in the central yellow part of the quince are shown. The sampling position is indicated in Fig. 1. With $\mu$-XRPD, information on the composition of each individual paint layer can be obtained. From these data, and consistent with the MA-XRPD data discussed above, the presence of a number of white/colorless compounds such as calcite and hydrocerussite in well-defined paint strata can be clearly visualized as well of that of yellow orpiment. These compounds can be readily assumed to have been original components of Nellius' paint(s). Again consistent with the MA-XRPD data, the presence of compounds that are likely to be secondary compounds such as palmierite, mimetite and schultenite can now be unambiguously linked to specific layers in the paint stratigraphy. The second lead-arsenate based rare mineral, mimetite $\left.\left(\mathrm{Pb}_{5}\left(\mathrm{AsO}_{4}\right)_{3} \mathrm{Cl}\right)\right)$ features a substantially higher $\mathrm{Pb}: \mathrm{As}$ atomic ratio (5:3) than schultenite (1:1). 

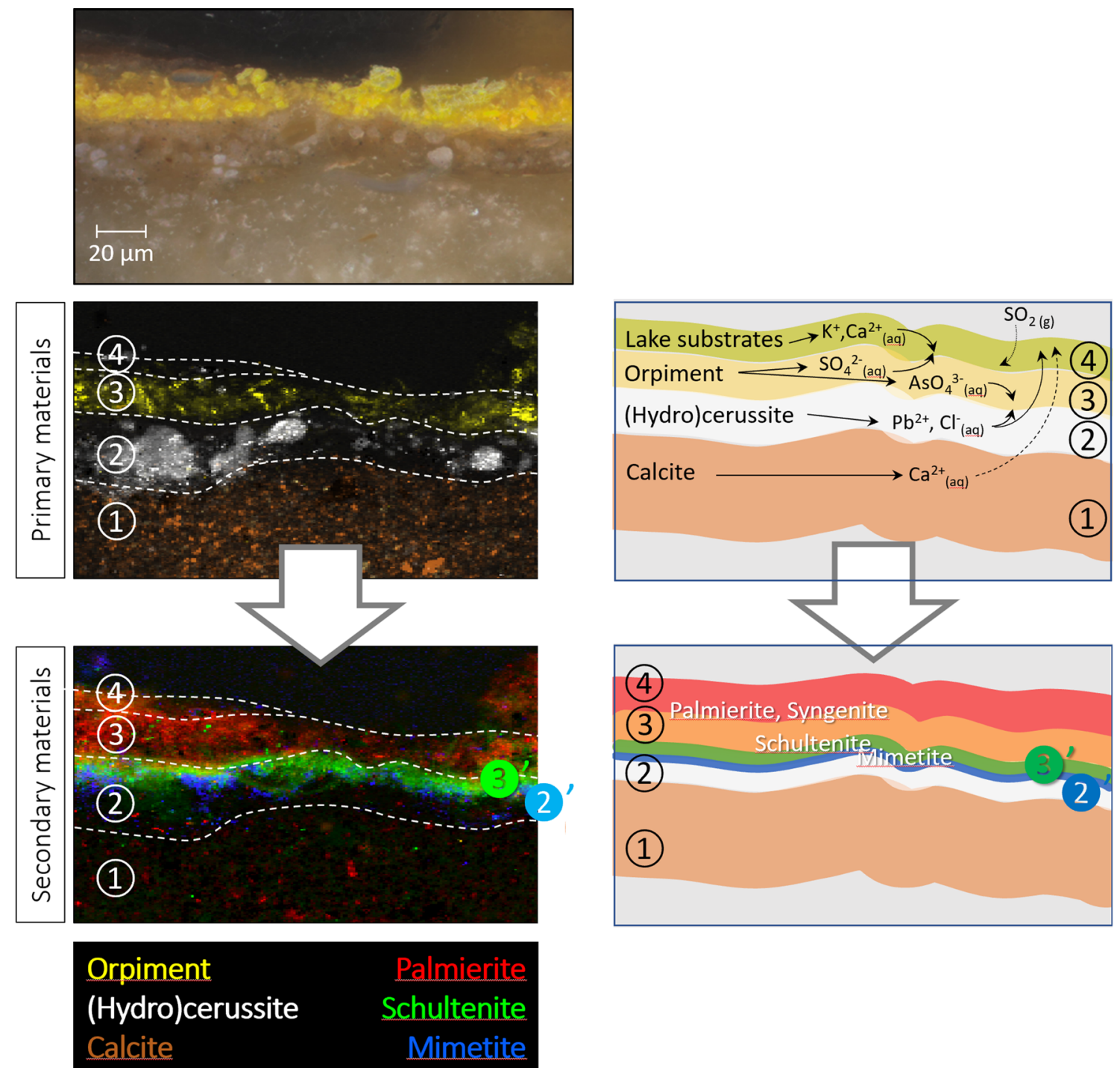

Fig. 4 Optical micrograph of scanned area $\left(200 \times 110 \mu \mathrm{m}^{2}\right)$ of cross sectioned paint sample R36-3 (top). In-depth distribution of primary compounds obtained by $\mu$-XRPD scanning (see Fig. 1 for sampling location): RGB composite maps of some primary compounds (middle panel) and secondary compounds (lower panel). As a result of the degradation processes that oxidize the original orpiment present in layer (3) and hydrolyze the lead white in layer (2), followed by migration of the resulting arsenate, sulfate, calcium and lead ions, at the interface between layers (2) and (3) (indicated as $\mathbf{2}^{\prime}$ and $\mathbf{3}^{\prime}$ ) but also at the surface of the paint (indicated by (4)) secondary compounds such as palmierite, syngenite, schultenite and mimetite precipitate

Previously, mimetite has been reported on three Hellenistic steles from Alexandria [45, 46], in several murals [47-49] and in one case was considered to be a degradation product formed from the interaction between orpiment and red lead $\left(\mathrm{Pb}_{3} \mathrm{O}_{4}\right)$ [50]. Schultenite was recently reported as a degradation product of orpiment, together with arsenolite $\left(\mathrm{As}_{2} \mathrm{O}_{3}\right)$, on a colonial American polychromed chest on stand [9]. Fully consistent with the observation of Fig. 4b, Vanmeert et al. have recently encountered both arsenates in degraded areas on several paintings by De Heem [11].
From the depth distributions of a number of primary compounds (Fig. 4), a relatively simple, four-layered structure of the original paint can be inferred, consisting of a ground layer (1) containing calcite $\left(\mathrm{CaCO}_{3}\right)$, covered by a second layer (2) containing coarse particles of cerussite $\left(\mathrm{PbCO}_{3}\right)$ and hydrocerussite $\left(2 \mathrm{PbCO}_{3} \cdot \mathrm{Pb}(\mathrm{OH})_{2}\right)$, which in turn is covered by a yellow layer (3) containing finely ground particles of orpiment $\left(\mathrm{As}_{2} \mathrm{~S}_{3}\right)$. Inside layers (2) and (3), also a few large grains of gypsum $\left(\mathrm{CaSO}_{4} \cdot 2 \mathrm{H}_{2} \mathrm{O}\right)$ can be observed in the $\mu$-XRPD maps. On top of layer (3), although not discernable by XRPD, a 
(yellow) lake layer (4) is present e.g. to create the effect of shading on the quince surface. This layer is visible in UV image of this sample (not shown).

It is highly relevant to establish where exactly in the original stratigraphy, the highest local concentration of the secondary products has formed. For the arsenates, unsurprisingly, this is at the interface between the Asrich orpiment layer (3) and the $\mathrm{Pb}$-rich lead white layer (2) (labelled (2' and (3' in Fig. 4). Next to that, inside/ near the top layer (4) also some arsenate minerals are present. On the basis of Fig. 4, it is possible to formulate a relatively simple mechanism of formation for the secondary products, consisting of essentially three steps: (i) release of specific ions as a result of (photo)degradation in their parent paint layers, (ii) migration of these ions towards other layers and (iii) local precipitation of one or more crystalline secondary products. One can imagine that in layers (2) and (3), light-induced and other degradation processes in first instance give rise to respectively mobile $\mathrm{AsO}_{4}{ }^{3-}, \mathrm{SO}_{4}{ }^{2-}$ and $\mathrm{Pb}^{2+}$ ions while from layer (1) $\mathrm{Ca}^{2+}$ ions can be released. The chemical transformation to produce the arsenate and sulfate ions from orpiment clearly is an oxidation process since the As(III)-species that are originally present in orpiment become $\mathrm{As}(\mathrm{V})$ species while the sulfidic counter ions become sulfate species, as already described more in detail by Keune et al. [9] and Vermeulen et al. [10]. This oxidation process can only take place in the presence of moisture and oxygen inside the porous paint, according to the following reactions:

$$
\begin{aligned}
& 2 \mathrm{As}^{3+}{ }_{(\mathrm{s})}+6 \mathrm{H}_{2} \mathrm{O}+\mathrm{O}_{2(\mathrm{~g})} \rightarrow 2 \mathrm{HAsO}_{4}{ }^{2-}{ }_{(\mathrm{aq})}+10 \mathrm{H}^{+}{ }_{(\mathrm{aq})} \\
& 3 \mathrm{~S}^{2-}{ }_{(\mathrm{s})}+12 \mathrm{O}_{2(\mathrm{~g})} \rightarrow 3 \mathrm{SO}_{4}{ }^{2-}(\mathrm{aq})
\end{aligned}
$$

$$
\begin{aligned}
& \mathrm{As}_{2} \mathrm{~S}_{3(\mathrm{~s})}+6 \mathrm{H}_{2} \mathrm{O}+13 \mathrm{O}_{2(\mathrm{~g})} \\
& \quad \rightarrow 2 \mathrm{HAsO}_{4}{ }^{2-}{ }_{(\mathrm{aq})}+3 \mathrm{SO}_{4}{ }^{2-}{ }_{(\mathrm{aq})}+10 \mathrm{H}^{+}{ }_{(\mathrm{aq})}
\end{aligned}
$$

(In the above equations, " $\mathrm{HAsO}_{4}{ }^{2-"}$ " should be understood to denote all protonated forms of arsenate ions, ranging from the fully protonated $\mathrm{H}_{3} \mathrm{AsO}_{4}$ to the completely deprotonated $\mathrm{AsO}_{4}{ }^{3-}$; the average degree of protonation is $\mathrm{pH}$ dependent.) The above redox reaction leads to the formation of acidic species and a lowering of the $\mathrm{pH}$ of the aqueous phase present in the paint. Either the latter is present as microdroplets of solution inside the porous paint layer (pore water) or as a absorbed layer of water molecules at a (polar) paint surface. In the latter case, the high polarity of the surface of the pigment grains may enhance the reaction rates. Through diffusion or a process of cyclic moisture evaporation/drying and water condensation inside/wetting of the paint layers, the acidic solution that originates in the orpiment layer (3) can reach the lead white layer (2) where the dissolution of the lead white can be enhanced above its 'normal' level. The release of $\mathrm{Pb}^{2+}$-ions from lead carbonates, in some cases leading to e.g. the in situ formation of lead soaps and other compounds, is a well-known and elaborately studied phenomenon (see e.g. [42]); the acidic groups of the oil binding medium are already sufficient to promote the dissolution of $\mathrm{Pb}^{2+}$ ions. This process consumes free protons and involves the release of $\mathrm{CO}_{2}$ :

$$
\begin{aligned}
& \mathrm{PbCO}_{3(\mathrm{~s})}+2 \mathrm{H}^{+}{ }_{(\mathrm{aq})} \rightarrow \mathrm{Pb}^{2+}{ }_{(\mathrm{aq})}+\mathrm{CO}_{2(\mathrm{~g})}+\mathrm{H}_{2} \mathrm{O} \\
& 2 \mathrm{PbCO}_{3} \cdot \mathrm{Pb}(\mathrm{OH})_{2(\mathrm{~s})}+6 \mathrm{H}^{+}{ }_{(\mathrm{aq})} \rightarrow 3 \mathrm{~Pb}^{2+}{ }_{(\mathrm{aq})} \\
& \quad+2 \mathrm{CO}_{2(\mathrm{~g})}+4 \mathrm{H}_{2} \mathrm{O}
\end{aligned}
$$

Since the concentration of $\mathrm{H}_{3} \mathrm{O}^{+}$ions in the aqueous phase will be the largest at the interface between the orpiment layer (3) and the lead white layer (2), it will be in this contact area (labelled with $\mathbf{2}^{\prime}$ in Fig. 4) that the highest concentration of $\mathrm{Pb}^{2+}$ ions in solution will be encountered. The further into the lead white layer the acidic solution diffuses/penetrates, the more it will become neutralized as $\mathrm{H}_{3} \mathrm{O}^{+}$ions are replaced by (solvated) $\mathrm{Pb}^{2+}$ ions.

At the orpiment-lead white interface area, we hypothesize that two streams of ions may encounter one another: on the one hand solvated arsenate ions that are formed in the orpiment layer and that are migrating towards the lead white layer, while on the other hand solvated $\mathrm{Pb}^{2+}$ ions move in the other direction. In this [already partially (?) neutralized] acidic solution, all necessary ions are available to allow precipitation of the arsenate mineral schultenite $\left(\mathrm{PbHAsO}_{4}\right)$. This precipitation reaction also consumes protons:

$$
\mathrm{Pb}^{2+}{ }_{(\mathrm{aq})}+\mathrm{HAsO}_{4}{ }^{2-}{ }_{(\mathrm{aq})} \rightarrow \mathrm{PbHAsO}_{4(\mathrm{~s})}
$$

It is interesting to note that slightly below the schultenite layer, i.e. slightly closer to the source of $\mathrm{Pb}^{2+}$ ions and slightly more distant from the source of $\mathrm{HAsO}_{4}{ }^{2-}$ ions, possibly at a location where the $\mathrm{pH}$ is slightly higher and the acid-base equilibrium between $\mathrm{HAsO}_{4}{ }^{2-}$ and $\mathrm{AsO}_{4}{ }^{3-}$ favours the presence of $\mathrm{AsO}_{4}{ }^{3-}$, a second rare arsenate mineral, mimetite $\left(\mathrm{Pb}_{5}\left(\mathrm{AsO}_{4}\right)_{3} \mathrm{Cl}\right)$ has precipitated (labelled $\mathbf{3}^{\prime}$ in Fig. 4):

$$
5 \mathrm{~Pb}^{2+}{ }_{(\mathrm{aq})}+\mathrm{Cl}^{-}{ }_{(\mathrm{aq})}+3 \mathrm{AsO}_{4}{ }^{3-}{ }_{(\mathrm{aq})} \rightarrow \mathrm{Pb}_{5}\left(\mathrm{AsO}_{4}\right)_{3} \mathrm{Cl}_{(\mathrm{s})}
$$

In addition, when we compare the value of the precipitation products of these two minerals $\left(\mathrm{K}_{\mathrm{s}, 25^{\circ} \mathrm{C}} \approx 10^{-23}-10^{-24}\right.$ for schultenite and $\mathrm{K}_{\mathrm{s}, 25{ }^{\circ} \mathrm{C}} \approx 10^{-76}-10^{-83}$ for mimetite) and finally consider that the effect of $\left[\mathrm{Pb}^{2+}\right]_{\mathrm{aq}}$, i.e. the equilibrium concentration of solvated $\mathrm{Pb}^{2+}$-ions in the aqueous 
phase, on the precipitation behavior is much larger in the case of mimetite than for schultenite, it becomes understandable why mimetite has precipitated closer to lead white layer (2) than schultenite. (The source of $\mathrm{Cl}^{-}$ions required for the formation of mimetite is not easily identified; however, many paintings and painters' materials generally contain an abundance of chlorides $[2-4,11,26,41]$ and the MA-XRF data of Fig. 3 (Cl-K map) also points out that it is present (at least at the surface). In this case, the lead white, likely produced by means of the Dutch stack process, is considered to be a primary source of $\mathrm{Cl}$.

In Fig. 4 we further see that the largest abundance of palmierite $\left((\mathrm{Na}, \mathrm{K})_{2} \mathrm{~Pb}\left(\mathrm{SO}_{4}\right)_{2}\right)$, a secondary compound formed by precipitation of solvated $\mathrm{Pb}^{2+}$ with $\mathrm{SO}_{4}{ }^{2-}$ and $\mathrm{K}^{+}$(and/or $\mathrm{Na}^{+}$) ions,

$$
\mathrm{K}^{+}{ }_{(\mathrm{aq})}+\mathrm{Pb}^{2+}{ }_{(\mathrm{aq})}+\mathrm{SO}_{4}{ }^{2-}{ }_{(\mathrm{aq})} \rightarrow \mathrm{K}_{2} \mathrm{PbSO}_{4(\mathrm{~s})}
$$

is situated at the surface (near/in layer (4)). Also this phenomenon and in particular the fact that this secondary lead sulfate mineral has not precipitated in the same location as the lead arsenate minerals becomes understandable when the higher solubility (and thus the larger $\mathrm{K}_{\mathrm{s}}$ value) of palmierite is taken into consideration $\left(\mathrm{K}_{\mathrm{s}, 25}{ }^{\circ} \mathrm{C} \approx 10^{-10}-10^{-8}\right)$. At $\left[\mathrm{Pb}^{2+}\right]_{\mathrm{aq}}$ levels that force the arsenates to precipitate locally, sulfate ions can still remain in solution and thus have the possibility to migrate over a larger distance. Thus, e.g. as a result of drying/condensation cycles, many (but not all) sulfate ions that were formed (or were originally present) inside orpiment layer (3) may have become transported to the original paint surface (top of layer (3) and/or lake layer, see Fig. 4) where they may have been forced to precipitate because of water evaporation (layer (4) in Fig. 4b). Depending on the available cations, several sulfates may have formed, including palmierite and syngenite. It follows that, if conditions are such that e.g. palmierite is precipitating, then also the less soluble minerals such as schultenite and mimetite will behave similarly, provided all required ions are present in the thin layer of evaporating solution present at the surface. Another relevant difference between the arsenate and sulfate salts is that a possible source of the sulfates is atmospheric $\mathrm{SO}_{2}$, making formation of the sulfates closer to the paint surface more probable that at greater depths.

Note: The observation that the above-mentioned arsenate minerals are not homogeneously distributed within the As-containing paint layer strengthens our initial assumption that they were formed in situ and were not already present at the time of painting.

\section{Conclusions}

We can conclude that by combining information about the lateral distribution of primary and secondary arsenate and sulfate minerals that are formed due to the (photo) degradation of the painters' pigment orpiment, with in-depth information obtained by microscopic analysis of a paint cross section, it is possible to formulate and substantiate a working hypothesis about the multistep mechanism that gives rise to the formation of secondary minerals. A three-step mechanism appears to be consistent with all observations: (i) formation of arsenate and sulfate ions as a result of (photo)degradation in their parent paint layer which also gives rise to soluble acidic species, (ii) migration of these ions (and the acidic solution they are dissolved in) towards other layers where dissolution of mainly $\mathrm{Ca}^{2+}$ and $\mathrm{Pb}^{2+}$ ions from calcite and lead white can take place and (iii) local precipitation of $\mathrm{Pb}$-containing arsenate and sulphate minerals both on the interfaces between As- and Pb-rich paint layers and at the paint surface.

This hypothesis permits to design laboratory experiments in which the degradation of orpiment can be realized and studied under controlled circumstances. Analysis of artificially degraded paint mock-up samples, especially at the microscopic level, will then allow to verify the formulated hypothesis.

More in general, the chemical maps discussed in this paper illustrate the added value that MA-XRPD can bring to the field of cultural heritage, not only for the identification of artist's materials, but also for the detection of degradation products and secondary compounds formed inside/at the surface of works of art. We consider that it may become a valuable new tool for in situ monitoring of restoration and cleaning treatments. The information that is provides, and in particular the macroscopic distributions of the alteration products, may also be employed to guide sampling campaigns to strategic areas of the artworks under examination. Nevertheless, it is also obvious that the lateral resolution of MA-XRPD imaging can still be improved to increase the readability of the images.

\section{Abbreviations}

MA-XRPD: macroscopic X-ray powder diffraction; MA-XRF: macroscopic X-ray fluorescence; $\mu$-XRF: microscopic $X$-ray fluorescence; $\mu$-XRPD: microscopic $X$-ray powder diffraction.

\section{Acknowledgements}

The authors thank the Rijksmuseum and their staff for the collaboration. We are also very grateful to the staff of PETRA-III Beamline P06 (DESY Research Centre, Hamburg, Germany) for their help and support during the synchrotron experiments.

\section{Authors' contributions}

SdM, EA and FV performed the measurements and contributed to the XRF and XRPD Data analysis; JS performed the XRPD data analysis and contributed to the making of the figures and to the discussion about them. KJ contributed 
to the research strategy and wrote most of the initial versions of the text and figures. NdK compiled the art historical information on M. Nellius. All authors contributed to research strategy, the discussion and interpretation of the results and to the final form of the text and figures. All authors read and approved the final manuscript.

\section{Funding}

The authors acknowledge financial support from the NWO (The Hague) Science4Arts 'ReVisRembrandt' project (AvL, JD), the GOA Project Solarpaint (University of Antwerp Research Council) (SdM) and the METOX project (Belgian Federal Science Policy) (FvM). Special thanks go to the support received from FWO, Brussels via projects G056619 N and G054719 N (GvdS, KJ) and from NWO, The Hague via project NICAS/3D2P (KK, NdK). Parts of the MA-XRPD scanner could be purchased thanks to InterReg Project Smart*Light.

\section{Availability of data and materials}

All the data are available within the manuscript.

\section{Competing interests}

The authors declare that they have no competing interests.

\section{Author details}

${ }^{1}$ AXES Research Group, Department of Chemistry, Faculty of Science, University of Antwerp, Groenenborgerlaan 171, 2020 Antwerp, Belgium. ${ }^{2}$ Heritage and Sustainability, Heritage Department, Faculty of Design Sciences, University of Antwerp, Blindestraat 9, 2000 Antwerp, Belgium. ${ }^{3}$ Rijksmuseum Amsterdam, Museumstraat 1, 1071 XX Amsterdam, The Netherlands. ${ }^{4}$ Museum Mauritshuis, Plein 29, 2511 CS The Hague, The Netherlands. ${ }^{5}$ University of Amsterdam, Science Park 904, 1098 XH Amsterdam, The Netherlands.

\section{Received: 9 May 2019 Accepted: 9 October 2019}

Published online: 16 October 2019

\section{References}

1. Zanella L, Casadio F, Gray KA, Warta R, Ma Q, Gaillard JF. The darkening of zinc yellow: XANES speciation of chromium in artist's paints after light and chemical exposures. J Anal At Spectrom. 2011;26(5):1090-7.

2. Mass J, Sedlmair J, Patterson CS, Carson D, Buckley B, Hirschmugl C. SR-FTIR imaging of the altered cadmium sulfide yellow paints in Henri Matisse's Le Bonheur de vivre (1905-6) - examination of visually distinct degradation regions. Analyst. 2013;138(20):6032-43.

3. Van der Snickt G, Dik J, Cotte M, Janssens K, Jaroszewicz J, De Nolf W, et al. Characterization of a degraded cadmium yellow (CdS) pigment in an oil painting by means of synchrotron radiation based X-ray techniques. Anal Chem. 2009;81(7):2600-10.

4. Van der Snickt G, Janssens K, Dik J, De Nolf W, Vanmeert F, Jaroszewicz J, et al. Combined use of synchrotron radiation based micro-X-ray fluorescence, micro-X-ray diffraction, micro-X-ray absorption near-edge, and micro-fourier transform infrared spectroscopies for revealing an alternative degradation pathway of the pigment cadmium yellow in a painting by Van Gogh. Anal Chem. 2012;84(23):10221-8.

5. Coccato A, Moens L, Vandenabeele P. On the stability of mediaeval inorganic pigments: a literature review of the effect of climate, material selection, biological activity, analysis and conservation treatments. Herit Sci. 2017;5:12

6. FitzHugh EW. Orpiment and Realgar. In: FitzHugh EW, editor. Artists' Pigments A handbook of their history and characteristics, vol. 3. London: Archetype Publications; 1997. p. 47-79.

7. Strbac N, Mihajlovic I, Minic D, Zivkovic D, Zivkovic Z. Kinetics and mechanism of arsenic sulfides oxidation. J Min Metall Sect B Metall. 2009;45(1):59-67.

8. Muralha VSF, Miguel C, Melo MJ. Micro-Raman study of Medieval Cistercian 12-13th century manuscripts: Santa Maria de Alcobaca, Portugal. J Raman Spectrosc. 2012;43(11):1737-46.

9. Keune K, Mass J, Meirer F, Pottasch C, van Loon A, Hull A, et al. Tracking the transformation and transport of arsenic sulfide pigments in paints: synchrotron-based X-ray micro-analyses. J Anal At Spectrom. 2015;30(3):813-27.
10. Vermeulen M, Nuyts G, Sanyova J, Vila A, Buti D, Suuronen JP, et al. Visualization of $\mathrm{As}(\mathrm{III})$ and $\mathrm{As}(\mathrm{V})$ distributions in degraded paint microsamples from Baroque- and Rococo-era paintings. J Anal At Spectrom. 2016;31(9):1913-21.

11. Vanmeert F, De Keyser N, Van Loon A, Klaassen L, Noble P, Janssens K. Transmission and reflection mode macroscopic $X$ ray powder diffraction (MA XRPD) imaging for the noninvasive visualization of paint degradation in still life paintings by Jan Davidsz. de Heem. Anal Chem. 2019:91(10):7153-61.

12. Thiel PJJv, Bruijn Kops CJd, Hoeben WAP, Kiers FE, Kloek WT, Loos WF, et al. All the paintings of the Rijksmuseum in Amsterdam : a completely illustrated catalogue : first supplement : 1976-91. Amsterdam: Rijksmuseum; 1992.

13. Buijsen E, Dumas C, Haags Historisch M. Haagse schilders in de Gouden Eeuw: het Hoogsteder Lexicon van alle schilders werkzaam in Den Haag 1600-1700. Den Haag: Kunsthandel Hoogsteder \& Hoogsteder; Waanders; 1998.

14. van der Willigen A, Meijer F. A dictionary of Dutch and Flemish still-life painters working in oils: 1525-1725. Leiden: Primavera Press: Netherlands Institute for art history; 2003.

15. Wallert A. Still lifes: techniques and style: an examination of paintings from the Rijksmuseum. Amsterdam: Rijksmuseum; Waanders; 1999.

16. Klein P. Dendrochronology report. https://rkd.nl/nl/explore/techn ical/5003006. Accessed 1 May 2019.

17. Meagher J. Food and drink in European painting, 1400-1800. In: Heilbrunn Timeline of Art History. New York: The Metropolitan Museum of Art; 2000. http://www.metmuseum.org/toah/hd/food/hd_food.htm Accessed May 2009.

18. Alfeld M, Pedroso JV, Hommes MV, Van der Snickt G, Tauber G, Blaas J, et al. A mobile instrument for in situ scanning macro-XRF investigation of historical paintings. J Anal At Spectrom. 2013;28(5):760-7.

19. Vanmeert F, De Nolf W, De Meyer S, Dik J, Janssens K. Macroscopic $X$-ray powder diffraction scanning, a new method for highly selective chemical imaging of works of art: instrument optimization. Anal Chem. 2018;90(11):6436-44.

20. Vanmeert F, De Nolf W, Dik J, Janssens K. Macroscopic X-ray powder diffraction scanning: possibilities for quantitative and depth-selective parchment analysis. Anal Chem. 2018;90(11):6445-52.

21. Schroer CG, Boye P, Feldkamp JM, Patommel J, Samberg D, Schropp A, et al. Hard X-ray nanoprobe at beamline P06 at PETRA III. Nucl Instrum Methods Phys Res Sect A. 2010;616(2-3):93-7.

22. De Nolf W, Vanmeert F, Janssens K. XRDUA: crystalline phase distribution maps by two-dimensional scanning and tomographic (micro) X-ray powder diffraction. J Appl Crystallogr. 2014;47(3):1107-17.

23. De Nolf W, Janssens K. Micro X-ray diffraction and fluorescence tomography for the study of multilayered automotive paints. Surf Interface Anal. 2010;42(5):411-8.

24. Alfeld M, Janssens K. Strategies for processing mega-pixel X-ray fluorescence hyperspectral data: a case study on a version of Caravaggio's painting Supper at Emmaus. J Anal At Spectrom. 2015;30(3):777-89.

25. De Meyer $S$, Vanmeert $F$, Janssens $K$, Storme $P$, editors. A mobile scanner for XRPD-imaging of paintings in transmission and reflection geometry. In: 6th Interdisciplinary ALMA conference; 2017 1-3 June 2017; Brno: Academy of Fine Arts in Prague.

26. De Keyser N, Van der Snickt G, Van Loon A, Legrand S, Wallert A, Janssens K. Jan Davidsz. de Heem (1606-1684): a technical examination of fruit and flower still lifes combining MA-XRF scanning, cross-section analysis and technical historical sources. Herit Sci. 2017;5:13.

27. Douglass DL, Shing CC, Wang G. The light-induced alteration of realgar to pararealgar. Am Mineral. 1992;77(11-12):1266-74.

28. Bindi L, Popova V, Bonazzi P. Uzonite, As4S5, from the type locality: single-crystal X-ray study and effects of exposure to light. Can Miner. 2003;41:1463-8.

29. Kyono A, Kimata M, Hatta T. Light-induced degradation dynamics in realgar: in situ structural investigation using single-crystal X-ray diffraction study and $X$-ray photoelectron spectroscopy. Am Miner. 2005;90(10):1563-70.

30. Matović V, Erić S, Kremenović A, Colomban P, Srećković-Batoćanin D, Matović $\mathrm{N}$. The origin of syngenite in black crusts on the limestone monument King's Gate (Belgrade Fortress, Serbia) - the role of agriculture fertiliser. J Cult Herit. 2012;13(2):175-86. 
31. Eric S, Matovic V, Kremenovic A, Colomban P, Batocanin DS, Neskovic M, et al. The origin of $\mathrm{Mg}$ sulphate and other salts formed on pure calcium carbonate substrate-Tufa stone blocks built into the Gradac Monastery, Serbia. Constr Build Mater. 2015;98:25-34.

32. Melcher $M$, Schreiner $M$. Leaching studies on naturally weathered potashlime-silica glasses. J Non-Cryst Solids. 2006;352(5):368-79.

33. Vettori S, Bracci S, Cantisani E, Riminesi C, Sacchi B, D'Andria F. A multi-analytical approach to investigate the state of conservation of the wall paintings of Insula 104 in Hierapolis (Turkey). Microchem J. 2016;128:279-87.

34. Marszalek M. Identification of secondary salts and their sources in deteriorated stone monuments using micro-Raman spectroscopy, SEM-EDS and XRD. J Raman Spectrosc. 2016;47(12):1473-85.

35. Newton R. Deterioration of glass. In: Newton R, Davison S, editors. Conservation of glass. Oxford: Butterworth-Heinemann; 1989. p. 135-64.

36. Garcia-Valles M, Gimeno-Torrente D, Martinez-Manent S, Fernandez-Turiel J. Medieval stained glass in a Mediterranean climate: typology, weathering and glass decay, and associated biomineralization processes and products. Am Miner. 2003;88(11-12):1996-2006.

37. Simova V, Bezdicka P, Hradilova J, Hradil D, Grygar T. X-ray powder microdiffraction for routine analysis of paintings. Powder Diffr. 2005;20(3):224-9.

38. Zeng QG, Zhang GX, Leung CW, Zuo J. Studies of wall painting fragments from Kaiping Diaolou by SEM/EDX, micro Raman and FT-IR spectroscopy. Microchem J. 2010;96(2):330-6.

39. Prikryl R, Svobodova J, Zak K, Hradil D. Anthropogenic origin of salt crusts on sandstone sculptures of Prague's Charles Bridge (Czech Republic): evidence of mineralogy and stable isotope geochemistry. Eur J Miner. 2004;16(4):609-17.

40. Sterpenich J. Cristallochimie des produits d'altération des vitraux médiévaux: application au vieillissement des déchets vitrifiés. Bull Eng Geol Environ. 2002;61(2):179-93.

41. Cotte M, Susini J, Solé VA, Taniguchi Y, Chillida J, Checroun E, et al. Applications of synchrotron-based micro-imaging techniques to the chemical analysis of ancient paintings. J Anal At Spectrom. 2008;23(6):820.
42. Van Loon A, Noble P, Boon JJ, editors. White hazes and surface crusts in Rembrandt's Homer and related paintings. In: ICOM Committee for Conservation 16th Triennial Conference; 2011; Lisbon.

43. Boon JJ, Oberthaler E. Mechanical weakness and paint reactivity observed in the paint structure and surface of The Art of Painting by Vermeer. In: Haag S, Oberthaler E, Pénot S, editors. Vermeer, Die Malkunst - Spurensicherung an einem Meisterwerk: Ausstellungskatalog des Kunsthistorischen Museums Wien. Salzburg: Residenz Verlag; 2010. p. 328-35.

44. Boon JJ. Chemistry underneath the painting surface: palmierite formation in/on a painting by Johannes Vermeer and by Jacob Jordaens using laboratory- and synchrotron-aided spectroscopic methods. Microsc Microanal. 2013;19(S2):1408-9.

45. Kakoulli I. Late Classical and Hellenistic painting techniques and materials: a review of the technical literature. Stud Conserv. 2002;47(sup1):56-67.

46. Leona $\mathrm{M}$. The materiality of art: scientific research in art history and art conservation at the metropolitan museum. Metrop Mus Art Bull. 2009:67(1):4-11.

47. Holakooei P, Karimy AH. Early Islamic pigments used at the Masjid-i Jame of Fahraj, Iran: a possible use of black plattnerite. J Archaeol Sci. 2015;54:217-27.

48. Brecoulaki H. La peinture funéraire de Macédoine: emplois et fonctions de la couleur IVe-lle s. av. J.-C. de Boccard, Paris 2006.

49. Buisson N, Burlot D, Eristov H, Eveno M, Sarkis N. The tomb of the three brothers in palmyra: the use of mimetite, a rare yellow pigmen, in a rich decorationt. Archaeometry. 2015;57(6):1025-44.

50. Hradil D, Hradilova J, Bezdicka P, Svarcova S, Cermakova Z, Kosarova V, et al. Crocoite $\mathrm{PbCrO} 4$ and mimetite $\mathrm{Pb}-5(\mathrm{AsO} 4)(3) \mathrm{Cl}$ : rare minerals in highly degraded mediaeval murals in Northern Bohemia. J Raman Spectrosc. 2014;45(9):848-58.

\section{Publisher's Note}

Springer Nature remains neutral with regard to jurisdictional claims in published maps and institutional affiliations.

\section{Submit your manuscript to a SpringerOpen ${ }^{\circ}$ journal and benefit from:}

- Convenient online submission

- Rigorous peer review

- Open access: articles freely available online

- High visibility within the field

- Retaining the copyright to your article

Submit your next manuscript at $\boldsymbol{\nabla}$ springeropen.com 